\title{
Chilling implications for science from the top
}

\section{Ian Wallis}

Ecology, Evolution and Genetics, Research School of Biology, Australian National University, Canberra 0200

The first of the 2008 presidential debates between Senator John McCain and the now-president, Barack Obama, was held at the University of Mississippi on September 26, 2008. It was primarily about foreign policy and national security, which, by definition, included the global financial crisis for which the Government had just allocated $\$ 700$ billion to solve. Added to that, another unnecessary expense - the war in Iraq, had eaten through $\$ 600$ billion. When asked what he would do as president to lead his country out of the financial crisis, John McCain stated:

"Well, the first thing we have to do is get spending under control in Washington. It's completely out of control."

One would imagine that he would then suggest avoiding wars and pulling the financial industry into line. But, instead, he said something with chilling implications for science:

“You know, we spent $\$ 3$ million to study the DNA of bears in Montana. I don't know if that was a criminal issue or a paternal issue, but the fact is that it was $\$ 3$ million of our taxpayers' money. And it has got to be brought under control."

How do we equate hundreds of billions of dollars with a few millions of dollars? Let's think about it as a jigsaw puzzle: a scientific jigsaw puzzle where we divide $\$ 1300$ billion into pieces worth $\$ 3$ million would have 433,333 pieces. On the $28^{\text {th }}$ of November 2008 the number of pieces increased to 700,000 when the US Government contributed another $\$ 800$ billion towards solving the financial crisis. By contrast, the largest conventional jigsaw puzzle - the $4 \times 2$ m monster with 24,000 pieces that Eric Smith conquered in 179 days in 2008 , is a fragment!

The challenge for scientists is to convince those at the top and the rest of society that genotyping the bears in Montana is money well spent.

\section{Introduction}

Two thousand and nine was a notable commemorative year for science. It was 400 years since Galileo stared at the sky with a telescope, 200 years since Charles Darwin's birthday and 150 years since he published a book that was to change the world - "The Origin of Species". Thanks to teething problems in 2008, there was at least one big scientific event in 2009 that was not commemorative: the switching on of the Large Hadron Collider (LHC). The LHC, sometimes known as the "Little Bang Machine", is designed to generate the conditions that existed billionths of a second after the universe came into existence. In doing so, it might help us understand the origins of the universe. But, who cares? And who cares about Darwin, the father of evolution, or Galileo, the father of modern physics? Probably far fewer people than care about who wins the rugby league grand final and probably a fraction of those who ponder the inevitable resurgence of the financial markets. Science is under siege and there is no greater threat to science than from the top - the very top.

What evidence is there for this opinion? The best evidence comes from the first of the 2008 presidential debates between Senator John McCain and the nowpresident, Barack Obama, held at the University of Mississippi on September 26, 2008 (New York Times 2008). This debate was primarily about foreign policy and national security. By definition, this included the global financial crisis that the Government hoped to solve with an injection of $\$ 700$ billion. Added to that, another unnecessary expense - the war in Iraq, had eaten through $\$ 600$ billion. But, when asked what he would do as president to lead his country out of the financial crisis, John McCain stated:

"Well, the first thing we have to do is get spending under control in Washington. It's completely out of control."

When pressed for the details, one would imagine him then citing the blatantly obvious: avoiding wars and pulling the financial industry into line. Instead, he said something with chilling implications for science or at least certain scientific disciplines:

"You know, we spent \$3 million to study the DNA of bears in Montana. I don't know if that was a criminal issue or a paternal issue, but the fact is that it was $\$ 3$ million of our taxpayers' money. And it has got to be brought under control."

It is all very well to defend Senator McCain by suggesting that his response was a spontaneous eruption, even humorous, but this was not a school debate. It was a debate between the frontrunners to lead the most powerful nation on Earth. Furthermore, it was not the first time that Senator McCain attacked the bear project. He made a similar earlier reference that caught the attention of Scientific American on February 8, 2008 (Ballantyne 2008) and continued it in television advertisements. Apart from describing the project, Scientific American made mockery of Senator McCain getting his facts wrong: in the five years to 2008, Congress did not spend 
$\$ 3$ million genotyping bears, they spent $\$ 4.8$ million! Three million or five million - it is peanuts compared to that budgeted for wars and for reviving the economy! For perspective, let's think about it as a jigsaw puzzle. A scientific jigsaw puzzle where we divide $\$ 1300$ billion into pieces or projects worth $\$ 3$ million would have 433,333 pieces. Imagine it - genotyping 433,333 species! By contrast, the largest conventional jigsaw puzzle - the 4 × 2 metre monster with 24,000 pieces that Eric Smith conquered in 179 days of 2008, is a fragment! (BBC News Magazine 2008).

What did the bear researchers get for their money? Rather a lot, I think. The same Scientific American article (Ballantyne 2008) says that 250 scientists and researchers set up hair-snag stations at thousands of locations over $32,000 \mathrm{~km}^{2}$ of grizzly bear habitat, some of them $50 \mathrm{~km}$ from the nearest road. In 2004, the team collected 34,000 samples of hair that it sent to a Canadian laboratory. The DNA in the hair revealed not only the species (grizzly or black bear), but also gender, and individual identity of the donor. Although it took only 14 weeks to collect the hair, it took two years to do the laboratory work and another year to analyse the data to estimate the size, distribution and genetic structure of the population. This study, led by Dr Kate Kendall, is now appearing in the literature (Boulanger et al. 2008; Kendall et al. 2008; Kendall et al. 2009) and sets the foundations for much exciting science and for conservation decisions that should ensure the grizzly's survival in the lower 48 states.

In contrast, let us head 14,000 kilometres south to the World Heritage site of Macquarie Island for two centuries of blind ecology, which started with the inadvertent release of feral animals and continues with one attempt after another to remove them. I doubt that a Royal Commission could find the underlying cause of the fiasco but it seems that a lack of funds in the last 50 years led to insufficient data, poor assumptions and bad decisions. Seemingly absent from the story are the hypothesis testing, constant monitoring and manipulative experiments to provide data to build predictive models about how species interact (Bergstrom et al. 2009).

Like many places on earth, things going wrong on this subantarctic island coincided with its discovery in 1810 and the plunder of its seal and penguin populations. No doubt, these first ships also brought the rodents whose numbers built quickly by feasting on a diet of nesting seabirds. Unless you are a rodent biologist, places teeming with rats and mice are unpleasant so sailors introduced cats. One cannot expect stranded sailors to exist on the fruits of the sea or on rodents and cats so rabbits followed, but not before the island lost two endemic flightless birds. Presumably, in their early years, a strongly seasonal food supply kept the cat population in check. Not only did rabbits decimate the island's vegetation but they also provided a year round diet for cats. Even worse for the island's ecology was that populations of both rabbits and cats continued to build. Nothing clobbers uninitiated rabbits like myxomatosis and the expected success greeted its introduction in the 1970s. As the vegetation recovered, the island's cats deprived of their diet of young succulent rabbit and old stringy rabbit plundered nesting seabirds, forcing a cat-eradication programme in the mid-1980s. But, looking in anticipation were the residual rabbits, now armed with resistance to the Myxoma virus. Now the Tasmanian Parks and Wildlife Service has a new plan: eradication of rabbits, rats and mice at an estimated cost of \$24 million - many times that of genotyping Montana's bears! Many may laud this eradication plan. It is, however, wasteful unless it occurs under an ecological umbrella that promotes excellent science rather than the sporadic and cash-starved data collection of the past. May I suggest the type of research outlined in a recent paper by Professor Stephen Simpson and colleagues, entitled "Modelling nutritional interactions: from individuals to communities" (Simpson et al. 2010). Macquarie Island offers an excellent setting for such research but there would need to be a superlative research facility that operates continuously. I cannot imagine the costs of building and maintaining such an institution but I can imagine the benefits: a generation of scientists able to tackle tomorrow's problems.

Unfortunately, this is probably a pipe dream. Most scientists in Australia struggle for funds and many who win Government grants, such as Australian Research Council Discovery Grants, get barely enough to cover the costs of technical assistance. Many rely instead on graduate students to do the work, thus giving away intellectual property and sometimes jeopardising projects. Interestingly, this lack of funding does not seem to be just an Australian problem for, recently, even the German Max Planck Society found itself short of money (Schiermeier 2002). This is surprising given its prestige - 17 Nobel Prizes since 1948, the workplace in 2007 of over 50 of the world's most highly cited researchers, a training place for thousands of scientists and a fertile place for invention (Max Planck Multimedia 2008). Likewise, examination of spending on scientific research in the USA reveals it to be propped up by defence spending, while spending in other areas languishes (Greenberg 2004).

It will take a tremendous initiative, especially in the present economic climate, to reverse this policy but there is more incentive now than ever. Governments in the developed world are throwing money at people to promote spending that might stimulate the economy. Unfortunately, there is no control on whether people spend the money or what they buy with it. This aside, the developed world's thirst for consumption is the cause of global climate change so this seems to be the perfect opportunity to redirect the economy. Let us throw money at science, rather than simply promoting consumption. Moreover, I mean science in the broadest sense - science in schools, conventional research and community research too. Indeed, let us provide incentives for anyone wanting to do science. All of this implies that science is important. Is it?

When confronted with this question, it is easy to answer in simple, practical terms. Science, most argue, improves our lives - often true if you live in the developed world. Science gives me the computer to research and write this article while recovering from a compound leg fracture. Of course, I would not be here were it not for the medical advances that stuck a titanium rod in my leg while 
keeping infection at bay. But, it is as easy to argue that without science we would not have frightening military equipment, the ability to pollute, to dredge the fish from the sea, to clear-fell forests and, well, dominate the earth. It seems that science is not so good after all and that its importance depends, very much, on individual circumstances. Let us conclude that these good and bad points balance each other.

Now let us think again, about why it's important for everyone to understand some science. Science is about seeing, not just looking. It teaches us how to think critically, to consider evidence and, in the scientific method, provides the means for separating what might be true from that which is false. Being human is about being inquisitive and science strengthens this, especially in children. I remember discovering electricity, first through a simple circuit connecting a battery, a bulb and a switch, and later by "welding" a screwdriver into a powerpoint! One hopes that, as adults, we become more sensible but we often lose our curiosity or don't work to maintain it. In doing so, we lose our contact with the world. Isaac Asimov (1974) described it most eloquently: "Every kid knows that he is going to be rewarded for reaching the age of sixteen, or whatever age he's allowed to get out, he's going to be rewarded by never having to go to school again, never having to open up another book, never having to learn another fact, never having to think another thought. We teach kids that to be grown up is to be able to be stupid for the rest of your life." It is acceptable not to look, not to see, not to know anything about science. You can be a presidential candidate for the most powerful nation on Earth and get away with mocking various scientific disciplines. I doubt, however, that you can fill the same shoes and make disparaging remarks about economics or religion.

Science costs a lot but, unlike random spending or poorly designed experiments, it offers huge future dividends, most notably an educated community. Science, along with seemingly other pointless endeavours like music and art is what separates us from all of the other organisms on the planet that share much of our DNA. Science explains why we dominate the planet. And, like it or not, if anything is going to save us from the developing environmental catastrophe that is Earth, it will be science. I suspect also that if we taught people to be inquisitive then governments would not so easily rush off to war and the financial industry would not be a law unto itself. Moreover, we could spend what are now wasted trillions of dollars on scientific research towards a sustainable future.

\section{References}

Asimov, I. 1974. The future of humanity. A lecture presented at Newark College of Engineering on November 8, 1974. http://www.asimovonline.com/oldsite/future_of_humanity.html (accessed 01/02/09).

Ballantyne, C. 2008. McCain's beef with bears?-pork. http://www.sciam.com/article.cfm?id=mccains-beef-with-bears (accessed 24/01/2009).

BBC News Magazine. 2008. How do you piece together $£ 10,000$ in cut-up notes? http://news.bbc.co.uk/1/hi/magazine/7765701. stm (accessed 24/02/2009).

Bergstrom, D., Lucieer, A., Kiefer, K., Wasley, J., Belbin, L., Pedersen, T. and Chown, S. 2009. Indirect effects of invasive species removal devastate World Heritage Island. Journal of Applied Ecology 46: 73-81.

Boulanger, J., Kendall, K. C., Stetz, J. B., Roon, D. A., Waits, L. P. and Paetkau, D. 2008. Multiple data sources improve DNA-based mark-recapture population estimates of grizzly bears. Ecological Applications 18: 577-589.

Greenberg, D. 2004. Bush accused of financially neglecting research. The Lancet 363: 1618.

Kendall, K. C., Stetz, J. B., Boulanger, J., Macleod, A. C., Paetkau, D. and White, G. C. 2009. Demography and genetic structure of a recovering grizzly bear population. Journal of Wildlife Management 73: 3-17.

Kendall, K. C., Stetz, J. B., Roon, D. A., Waits, L. P., Boulanger, J. B. and Paetkau, D. 2008. Grizzly bear density in Glacier National Park, Montana. Journal of Wildlife Management 72: 1693-1705.

Max Planck Multimedia. 2008. Max Planck Society outstanding achievements. http://www.mpg.de/english/ aboutTheSociety/missionStatement/achievements/index.html (accessed 01/02/09)

New York Times. 2008. The first presidential debate. http:// elections.nytimes.com/2008/president/debates/transcripts/firstpresidential-debate.html (accessed 01/12/2008).

Schiermeier, Q. 2002. Funding freeze leaves eastern Germany out in the cold. Nature 420: 452.

Simpson, S. J., Raubenheimer, D., Charleston, M. A., Clissold, F. J. and the ARC-NZ Vegetation Function Network Herbivory Working Group. 2010. Modelling nutritional interactions: from individuals to communities. Trends in Ecology and Evolution 25: 53-60. 